\title{
Organizational Transformation of Indonesian Logistics Board
}

\author{
La Ode Amijaya Kamaluddin \\ Universitas Negeri Makassar, \\ Makassar, South Sulawesi, Indonesia
}

\begin{abstract}
Organizational transformation in BULOG (National Logistic Agency) is considerably important because of the crucial role in relation with the scheme of government policy in the provision of basic needs. This study reviews the policy of BULOG transformation. Moreover, BULOG transformation is done through a series of policies, programs and processes that take place simultaneously. The policy and programs of the transformation concern the aspects of the laws and regulations, organizations and human resource, operational, and financial. Changes in the organization of the transformation process are in terms of vision, value, status, and institutional management. The culmination of the organizational transformation is the implementation of Good Corporate Governance. This paper suggests the significance of continues socialization in order to be sustainable transformation process.
\end{abstract}

Keywords- organizational transformation, public company, national logistics agency, good corporate governance

\section{INTRODUCTION}

The focus of this paper is the transformation of the organizational culture on BULOG. In the development of an organization, organizational transformation is inevitable. The main source of the transformation is essential in order that the organization can adapt quickly along with the rapid change on business. The decision makers often take the transformation of the organization to be able to survive.

BULOG experienced the organizational transformation that requires the good adjustment of the values, vision and mission, system management, and organizational culture. By looking at back before transformation, BULOG was more a powerful media, whereas BULOG aims to be a more stable company after the transformation.

This demand would be failed to achieve if the organization still based on the old system and value but how to think, how to look at the competitors as well as the market. Since 2007, BULOG has been experiencing the transformation process for the better position in addressing and responding the challenges of new business [1]. Moreover, the business world is changing rapidly and new desires arise promptly within the company.

During this period, the attention of scientists to BULOG is in distant on organizational transformation. Meanwhile, research on the transformation of the organization has been widely studied [2]-[7]. These research different from what is discussed in this paper in terms of focus and aspects of cultural transformation within the organization.

To perform the transformation, organizations desire a wide range of policy/program, and a reliable leader to be able to take the right choices. The culture of the organization influences the success of the transformation. The core values and sub culture adopted by the company will change along with the management changes. What is interesting is that not all people are willing to accept the change, so it turned into a reject those changes. In a contrary the transformations BULOG is a manifestation of the wish to be superior company and trusted in the food sovereignty. Transformation leads the BULOG to take role based on the mandate by the government to secure the staple food prices, food management, and food distribution to certain segments of society [8]. This is the strategy for national food security.

\section{METHOD}

The research style is qualitative with the descriptive type of analysis that attempts to describe complex social realities through simplification and classification by utilizing the conceptions of analytic social symmetry [9]. The focus of research is the process of transformation, organizational transformation, organizational culture in the transformation process. Research subjects were 14 people, research informants 3 people. Primary and secondary data types. Interview data collection techniques, cyclical circulation.

\section{TRANSFORMATIONAL CONTEXT}

BULOG organizational transformation is worthy since the roles changes according to the scheme of complex policy. In the beginning, BULOG played the significant role in a very strong and strategic position directly under the President of the Republic of Indonesia. However, the administration of BULOG was under the coordination of the State Secretariat. This led to its BULOG privilege that has a special authority, which is free from government regulations and continue until 2001. As a result, BULOG enjoy comfort zone for 28 years [10]. Basically, the privilege position of BULOG caused by duties and functions are important to save public life.

However, along with the global economic developments, the principal task of BULOG narrowed to only control prices and manage the supply of rice and sugar [11]. This job carries out government duties in the field of logistics management, which is directly responsible to the President. The main context resulting in the transformation of BULOG is the pressure by the World Bank. The pressure resulted significant decrease of BULOG role in supporting the success of food distribution system. Organizational change is relisting the organizational components to improve the efficiency and effectiveness of the organization.

Given the importance of changes in the fast-paced setting, the organization brings forward the change since the delay will confront the organization in the process of degeneration. 
-numging .... public corporation, BULOG is still able to carry out public duties imposed by the government. Particularly, BULOG contributes to the security of the base price of the grain purchase, rice distribution to the poor foodinsecure, fertilization national stock for various public purposes for emergencies and public interests efforts to control price volatility. In addition, BULOG operations can contribute to society as one of the economic boards to carry out the business functions that go along with to the law and the rules of public transparency.

\section{POLICY, PROGRAM, AND TRANSFORMATION PROCESS}

An operational aspect of BULOG prioritizes public services aims at creating a stable food security. This public service mission remains focused on activities that can provide benefits to stakeholders including farmers, businessmen, traders, and consumers. Hence, BULOG run programs to implement procurement policies such as grain and rice to ensure that farmers can get the price in accordance with the basic purchase price based on the government policy [8]. The transformation target of BULOG improves public services for satisfactory results. Therefore, transformation within the organization carried out in order to provide the public services.

A financial aspect through a series of steps aims at creating management more accountable and transparent financial. Each unit prepared the budget and administration of separate financial statements as the for interim financial statements and annual reports. Moreover, each unit is given delegation and authorities in transactions with outsiders. The record of daily stock using a standard cost though in the final assessment would use actual cost method. Development on transparency and accountability comprises an important part of the transformation in the organization. It seems that the organizational transformation of BULOG includes many dimensions and levels that eventually involve a paradigm shift. Transformation comprises the process of change as the requirement for corporation to be better in addressing and responding to the challenges of new business. Moreover, the business competition is changing rapidly.

Based on the above, it appeared that organizational transformation occurred in BULOG with many dimensions, levels, not continuous so that eventually will involve a paradigm shift [12]. The changes in the organization so that towards the desired state in the future. The transformation that occurs so that the process changes required by a country to position itself to better respond to and address the challenges of new business, the business environment has changed rapidly and new desires that arise from within the organization.

\section{GOOD COORPORATE GOVERNANCE ON TRANSFORMATION}

The reform of State-Owned Enterprises (SEO) expects their governance implement the Good Public Governance (GPG) as well as Good Corporate Governance (GCG). These two principles should be applied together since given SOE encompass a corporate entity as well as involve public institutions that contribute to the bureaucracy and other political tools, such as the parliament and even political parties [13]. Willingness bureaucracy and political parties in SOE release as purely a business entity that requires the implementation of GPG [14].
Organizational change which is one form of change in the concept of paradigm shift, mindset and pattern of work triggered by the drastic external changes both from the legal, political, economic and social aspects which ultimately shift the vision and mission of the organization [15].

The essence of corporate governance is improving corporate performance through supervision or monitoring management performance and accountability of management to other stakeholders in a good framework of rules and regulations. In the implementation of GCG in enterprise is essential for the company to undergo a careful phase based on an analysis of the situation and condition of the company, and the level of readiness. Thus, the application of GCG can administrate effortlessly and get the support from all elements in the company [16].

Results of research on the implementation of GCG in BULOG include several stages. Preparation Phase consists of awareness building, GCG assessment, and GCG manual building. Awareness building is the first step to build awareness about the importance of good corporate governance and a shared commitment in its implementation. This phase needs asking the help of independent experts from outside the company through seminars, workshops, and discussion groups [17].

GCG Assessment is an attempt to measure, or more precisely map the company in determining the GCG today. This step is necessary to ensure the starting point level of GCG implementation and to identify appropriate measures to prepare the infrastructure and corporate structure that is conducive to the effective implementation of GCG. In other words, GCG assessment is needed to identify what aspects that need attention first and what steps to make it come to pass.

GCG manual building is the following steps after GCG assessment was done. GCG is manageable based on the results of mapping the readiness degree of companies and identification of priority implementation, preparing manuals, and guidelines for the implementation. Independent experts from outside the company can help the manual preparation.

The implementation of GCG in BULOG was a response to signed integrity agreement in the implementation of BULOG performance. The benefit is avoid corruption, improve the credibility of management, improve the performance of companies devoted to the achievement of key performance indicator, increasing healthy working environment and perpetuate. The result of the integrity pact is an increase in domestic rice procurement. Implementation of the integrity pact is a reflection of behavioral guidelines (code of conduct) [18]. This guideline is a moral and officially ethical standard.

Important changes of the transformation process contributed significantly to individual and organizational processes. Hence, the culture puts pressure on individuals to act in a certain direction, think and act consistently with the circumstances and needs of the organization. Cultural organizations formed as a result of the transformation of the organization would be the glue to reach the goal and get a positive response from both employees and management.

\section{CONCLUSION}

Transformation in BULOG is done through a series of policy, program, and process take place simultaneously. Policy and programs involve aspects of the laws and regulations, organizations and human resource instruments, human resource transformation, operational, and financial aspects. Changes in the organization of the transformation process concerning the vision, value, status, and institutional 

transformation through the implementation of GCG, which in turn formed a new culture that is in respect of conditions of employment, leadership practices, management style, the unify employees, the company's emphasis, and ratings the success of the organization. Transformation requires more intensive dissemination of the values, vision and mission of the organization to all employees. Consolidating the transformation to produce organizational change is more planned and measured.

\section{REFERENCES}

[1] S. Robinson, M. El-Said, and N. N. San, "Rice policy, trade, and exchange rate changes in Indonesia: A general equilibrium analysis," $J$. Asian Econ., vol. 9, no. 3, pp. 393-423, 1998.

[2] B. Horwitz, The transformation of the Organization of American States: A multilateral framework for regional governance. Anthem Press, 2011.

[3] J. I. Porras and R. C. Silvers, "Organization development and transformation,” Annu. Rev. Psychol., vol. 42, no. 1, pp. 51-78, 1991.

[4] G. Gemmill and C. Smith, "A dissipative structure model of organization transformation," Hum. Relations, vol. 38, no. 8, pp. 751766, 1985

[5] S. L. Shirk, "Recent Chinese labour policies and the transformation of industrial organization in China," China Q., vol. 88, pp. 575-593, 1981.

[6] W. Streeck, "The transformation of corporate organization in Europe: an overview," Institutions, Innov. Growth. Cheltenham Edward Elgar, pp. 4-44, 2003.

[7] E. K. Wilson, "What counts in the death or transformation of an organization," Soc. Forces, pp. 259-280, 1985.

[8] R. Robison, Indonesia: The rise of capital. Equinox Publishing, 2009.

[9] G. King, R. O. Keohane, and S. Verba, Designing social inquiry: Scientific inference in qualitative research. Princeton university press, 1994.

[10] H. W. Dick, The emergence of a national economy: an economic history of Indonesia, 1800-2000. University of Hawaii Press, 2002.

[11] C. P. Timmer, "Does Bulog stabilise rice prices in Indonesia? Should it try?," Bull. Indones. Econ. Stud., vol. 32, no. 2, pp. 45-74, 1996.

[12] W. L. French, C. Bell, and R. A. Zawacki, Organization development and transformation: Managing effective change. Macmillan/McGrawHill School, 2005.

[13] J. Heath and W. Norman, "Stakeholder theory, corporate governance and public management: what can the history of state-run enterprises teach us in the post-Enron era?," J. Bus. ethics, vol. 53, no. 3, pp. 247265, 2004.

[14] N. Gaus, S. Sultan, and M. Basri, "State Bureaucracy in Indonesia and its Reforms: An Overview," International Journal of Public Administration. pp. 1-12, 2016.

[15] T. A. Birkland, An introduction to the Policy Process Theories, Concepts, and Models of Public Policy Making, Third. New York: Routledge, 2015.

[16] L. F. Klapper and I. Love, "Corporate governance, investor protection, and performance in emerging markets," J. Corp. Financ., vol. 10, no. 5, pp. 703-728, 2004.

[17] M. Lipton and J. W. Lorsch, "A modest proposal for improved corporate governance,” Bus. lawyer, pp. 59-77, 1992.

[18] S. Arjoon, "Corporate governance: An ethical perspective," J. Bus. ethics, vol. 61, no. 4, pp. 343-352, 2005. 